\title{
The Effect Of Food On The Pharmacokinetic Properties And Bioequivalence Of Two Formulations Of Levocetirizine Dihydrochloride In Healthy Chinese Volunteers [Erratum]
}

\author{
Cheng Y, Lin BJ, Guo JH, et al. Drug Des Devel Ther. \\ 2019;13:3625-3634.
}

On page 3633, the "Funding" section is missing from the published paper.

The funding section should read before the Disclosure section as follows:

\section{Funding}

This study was supported by the Fujian Science and Technology Innovation Joint Project (no. 2017Y9036) and Fujian Health and Family Planning Young and Middle-aged Talents Training Project (no. 2018-ZQN-35).

\section{Publish your work in this journal}

Drug Design, Development and Therapy is an international, peerreviewed open-access journal that spans the spectrum of drug design and development through to clinical applications. Clinical outcomes, patient safety, and programs for the development and effective, safe, and sustained use of medicines are a feature of the journal, which has also been accepted for indexing on PubMed Central. The manuscript management system is completely online and includes a very quick and fair peer-review system, which is all easy to use. Visit http://www. dovepress.com/testimonials.php to read real quotes from published authors. 